\title{
Variation of cow's milk composition across different daily milking sessions and feasibility of using a composite sampling
}

\section{Carlos Bondan ${ }^{1}$ iD Jéssica Aneris Folchini ${ }^{2}$ iD Mirela Noro ${ }^{3}$ Karine Martini Machado ${ }^{4}$ Eduardo Muhls ${ }^{4}$ Félix Hilário Diaz González ${ }^{5}$}

${ }^{1}$ Programa de Pós-graduação em Agronomia (PPGAGRO), Serviço de Análises de Rebanhos Leiteiros (SARLE), Universidade de Passo Fundo (UPF), 99052-900, Passo Fundo, RS, Brasil. E-mail:carlosbondan@gmail.com. .Corresponding author.

${ }^{2}$ Programa de Pós-graduação em Agronomia (PPGAGRO), Universidade de Passo Fundo (UPF), Passo Fundo, RS, Brasil.

${ }^{3}$ Curso de Medicina Veterinária, Universidade Federal do Pampa (Unipampa), Uruguaiana, RS, Brasil.

${ }^{4}$ Universidade de Passo Fundo (UPF), Passo Fundo, RS, Brasil.

${ }^{5}$ Faculdade de Veterinária, Universidade Federal do Rio Grande do Sul (UFRGS), Porto Alegre, RS, Brasil.

ABSTRACT: This study vised to detect possible changes in chemical and cellular composition of cow's milk at different milking sessions and to test if proportional or composite milk sampling can be used instead of separate milk analysis. Two experiments were conducted: one in cows milked thrice daily and the other one in cows milked twice daily. In both experiments, three milk samples were collected from each cow in each milking session in order to determine milk composition at each milking; to have a composite sample, i.e., a single sample from the same aliquots of milk from each milking session; and to have a proportional sample, i.e., a single sample from each milking session in a volume proportional to milk volume yielded. Fat content and fat to protein ratio were higher in the afternoon on both experiments. Protein content was larger in the afternoon on cows milked twice daily, but not on cows milked thrice daily. Lactose level was not different across the milking sessions in any of the experiments. The urea level was higher in the afternoon and evening milking on cows milked thrice daily, and in the morning milking on cows milked twice daily. Somatic cell count did not differ between milking in any experiment. No difference in milk composition was noted between proportional and composite samples on cows milked thrice or twice daily. The collection of proportional and composite samples is recommended in twice or thrice daily milking sessions so that the analysis of milk components becomes more easy and cheap.

Key words: composite sample, milk composition, milk yield, milk somatic cells, proportional sample.

Variação da composição do leite de vaca em diferentes turnos diários de ordenha e viabilidade de usar uma amostragem composta

RESUMO: Este estudo visou detectar possíveis mudanças na composição química e celular do leite de vaca em diferentes sessões de ordenha, e testar se a amostragem de leite proporcional ou composta pode ser usada em vez de uma análise separada do leite. Dois experimentos foram conduzidos: um em vacas ordenhadas três vezes ao dia e outro em vacas ordenhadas duas vezes ao dia. Em ambos os experimentos, três amostras de leite foram coletadas de cada vaca em cada ordenha: para determinar a composição do leite em cada ordenha; ter uma amostra composta, isto é, uma única amostra das mesmas alíquotas de leite de cada sessão de ordenha; e ter uma amostra proporcional, ou seja, uma única amostra de cada sessão de ordenha em um volume proporcional ao volume de leite produzido. O conteúdo de gordura e a relação gordura:proteina foram maiores no período da tarde nos dois experimentos. O conteúdo de proteina foi maior à tarde nas vacas ordenhadas duas vezes ao dia, mas não nas vacas ordenhadas três vezes ao dia. O nível de lactose não foi diferente nas sessões de ordenha em nenhum dos experimentos. O nível de ureia foi maior à tarde è à noite, nas vacas ordenhadas três vezes ao dia e, pela manhã, nas vacas ordenhadas duas vezes ao dia. A contagem de células somáticas não diferiu entre as ordenhas em nenhum experimento. Não houve diferença na composição do leite entre as amostras proporcionais e compostas em vacas ordenhadas três vezes ao dia. Recomenda-se a coleta de amostras proporcionais e compostas em duas ou três sessões diárias de ordenha, para que a análise dos componentes do leite se torne mais fácil e barata.

Palavras-chave: amostra composta, composição do leite, produção de leite, células somáticas do leite, amostra proporcional.

\section{INTRODUCTION}

The physicochemical and cellular composition of milk has been utilized as a criterion for determining the price paid to dairy producers and for identifying problems with herd management (GONZALEZ et al., 2000). Among milk chemical components, fat and protein are widely used to monitor cows' nutritional status. High-roughage diets tend to augment fat content, whereas those rich in concentrates increase milk production, but decrease fat content (BAUMAN \& GRIINARI, 2003). Protein levels are less affected by nutrition when compared to fat content, and their reduction is associated with low- 
protein and/or low-carbohydrate diets (MURPHY \& O'MARA, 1993). The lack of synchronous energy and protein ruminal degradation increases milk urea concentrations, followed by poor supply of ammonia for microbial synthesis (NORO \& WITTWER, 2012). The fat to protein ratio (F:P) may be used to indicate dairy cows' energy balance (CUCUNUBO et al., 2013), as well as the presence of ruminal acidosis (PALMQUIST et al., 1993). It has been established that fat percentage has more milking-to-milking variations than protein (QUIST et al., 2008). Fat percentages may be 0.32 points higher and protein percentage 0.09 higher in the evening (GILBERT et al., 1973). The variation in the two more important components of milk, fat and protein, across milking stands out the need for adequate sampling in a dairy improvement program.

Analytical results of milk composition were affected by sampling method (NIELSEN et al., 2005). In order to reduce labour costs, it has been proposed that an individual sample, obtained from milk aliquots from the milking session can be used for determination of milk composition (MEINERT et al., 1996). However, sampling only one milk sample in the day may lead to misinterpretation due to milkingto-milking variation. It could be more practical to analyse only one milk sample; although, based on all milking sessions. The aim of this study was to assess possible changes in cow's milk chemical and cellular composition from different milkings and to assess two composite and proportional sampling methods.

\section{MATERIALS AND METHODS}

Two experiments were conducted in Rio Grande do Sul (Brazil's southernmost state) on two dairy farms. Experiment 1, conducted with 127 Holstein cows (160 days in milking) milked thrice daily (Farm A: $28^{\circ} 10^{\prime}$ south latitude, meridian 52 $50^{\prime}$ west longitude, altitude $598 \mathrm{~m}$ ). Experiment 2, conducted with 78 Holsteins cows (189 days in milking) milking twice daily (Farm B: $28^{\circ} 28^{\prime}$ south latitude, meridian 52 49' west longitude, altitude $499 \mathrm{~m}$ ). The cows of two experiments were raised in a semihoused system.

The diet of two experiments consisted of corn and oats whole-crop silage, oat and Italian ryegrass hay, and ground corn concentrate, soybean bran, wheat bran, buffering agents, and minerals. The feed was mixed and distributed by a Total Mix wagon in protected troughs in the morning, and as supplemental food source, cows were allowed to graze on Bermuda grass (Cynodon dactylon). Characteristics of the diets and animals are shown in table 1 . Water was available from the feeding area, from the waiting area and at the exit of the milking parlour.

At the end of each milking session, the milk produced and three milk samples were

Table 1 - Diet composition (dry matter base) and cows' characteristics on the two experiments.

\begin{tabular}{|c|c|c|}
\hline Parameter & Experiment 1 & Experiment 2 \\
\hline $\mathrm{N}$ & 127 & 78 \\
\hline Average live weight (kg) & 680 & 660 \\
\hline Supply of dry matter/day (kg/day) & 26.1 & 21.4 \\
\hline Neutral detergent fiber (kg/day) & 8.6 & 6.0 \\
\hline Metabolizable energy (Kcal/kg/day) & 2.4 & 2.5 \\
\hline Crude protein (kg/day) & 3.9 & 3.8 \\
\hline Minerals and buffering agents (kg) & 0.95 & 0.73 \\
\hline Number of lactations (mean) & 2.35 & 2.32 \\
\hline Heifers $(\%)$ & 33.0 & 39.4 \\
\hline Cows with 2-3 calving (\%) & 49.0 & 50.6 \\
\hline Cows with more than 3 calving (\%) & 18.0 & 10.0 \\
\hline Days in milk (DIM, mean) & 160 & 189 \\
\hline Cows with 6-60 DIM (\%) & 11.9 & 9.0 \\
\hline Cows with 61-120 DIM (\%) & 22.8 & 29.5 \\
\hline Cows with 120-220 DIM (\%) & 43.3 & 27 \\
\hline Cows with > 220 DIM (\%) & 18.0 & 34.5 \\
\hline
\end{tabular}

DIM: Days in milk. 
collected from each cow on the Waicato brand devices. The first sample contained $40 \mathrm{~mL}$ of milk for determination of milk composition in the corresponding session (Experiment 1: morning, afternoon and evening; Experiment 2: morning and afternoon). The second one was used for the composite sample, with equal aliquots of milk from each milking session (Experiment $1=13.3 \mathrm{~mL}$; Experiment $2=20 \mathrm{~mL}$ ) which were then mixed in a single sample for analysis; and the third one was used for the proportional sample, that is the volume of the sample in a milking session was proportional to the milk total volume yielded in each session, and then the samples were mixed in a single sample for analysis. Samples were stored in flasks with bronopol as preservative and kept at $8{ }^{\circ} \mathrm{C}$. The milk was analysed on the day following its collection using a combination system (Delta Instruments), consisting of SomatoScop CA3A5 for somatic cell count (SCC) by flow cytometry, and of LactoScop FT1 for determination of milk chemical composition (fat, protein, lactose and urea) by the near infrared test. The somatic cell counts were logtransformed (base 10) in order to obtain homogeneous variance. The data from two experiments were analysed individually by the IBM SPSS software version 19.0. Normality was assessed by the Levene test and homoscedasticity was verified by Bartlett's test. Milk composition data were submitted to ANOVA $\left(\mathrm{Y}_{\mathrm{i}}=\mu+\right.$
$\mathrm{S}_{\mathrm{i}}+\varepsilon_{\mathrm{i}}$, where: $\mathrm{Y}_{\mathrm{i}}=$ calculated effect, $\mu=$ mean, $\mathrm{S}_{\mathrm{i}}=\mathrm{i}$-th effect of the sample, and $\varepsilon_{\mathrm{ij}}=$ error) and the means were compared by Tukey's test. Differences were considered to be significant when $\mathrm{P}<0.05$.

\section{RESULTS}

Table 2 shows the means ( \pm standard deviation) of milk composition, somatic cell count (SCC), and milk yield of each milking session, as well as those of the proportional and composite samples. No differences were observed between proportional and composite samples regarding milk composition and SCC. On both experiments, milk yield was higher in the morning than in the afternoon. However, milk yield of afternoon was larger than the evening in cows milked thrice daily. In these cows, the afternoon milking session revealed higher fat content compared to the morning and evening sessions. In cows milked twice daily, the afternoon milking showed higher fat content than the morning one. The F:P ratio showed similar tendencies to those of fat content between milking sessions. Independently of the number of daily milking, the afternoon milking had the highest $\mathrm{F}: \mathrm{P}$ ratio compared to the other milking sessions; however, F:P ratios were similar between composite and proportional samples.

Table 2 - Means ( \pm SD) of milk yield and composition of individual samples on experiments conducted with cows with three (Experiment 1) or two (Experiment 2) daily milkings and of composite or proportional samples.

\begin{tabular}{|c|c|c|c|c|c|c|c|}
\hline $\begin{array}{l}\text { Milking } \\
\text { sessions }\end{array}$ & Fat $(\%)$ & Protein $(\%)$ & $\begin{array}{c}\text { Fat to } \\
\text { protein ratio }\end{array}$ & $\begin{array}{c}\text { Lactose } \\
(\%)\end{array}$ & Urea $(\mathrm{mg} / \mathrm{dL})$ & SCC & $\begin{array}{l}\text { Milk yield } \\
\text { (L/cow/day) }\end{array}$ \\
\hline \multicolumn{8}{|c|}{ 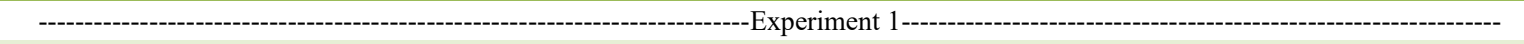 } \\
\hline $\begin{array}{l}\text { Morning } \\
(06: 00)\end{array}$ & $3.28 \pm 0.52^{c}$ & $2.91 \pm 0.29$ & $1.13 \pm 0.15^{\mathrm{c}}$ & $4.56 \pm 0.21$ & $14.10 \pm 2.91^{\mathrm{c}}$ & $2.05 \pm 0.77$ & $13.1 \pm 3.2^{\mathrm{a}}$ \\
\hline $\begin{array}{l}\text { Afternoon } \\
(14: 00)\end{array}$ & $3.98 \pm 0.54^{\mathrm{a}}$ & $2.98 \pm 0.29$ & $1.34 \pm 0.17^{\mathrm{a}}$ & $4.55 \pm 0.19$ & $15.67 \pm 2.14^{\mathrm{ab}}$ & $2.25 \pm 0.72$ & $10.5 \pm 2.5^{\mathrm{b}}$ \\
\hline $\begin{array}{l}\text { Evening } \\
(22: 30)\end{array}$ & $3.39 \pm 0.49^{c}$ & $2.90 \pm 0.29$ & $1.17 \pm 0.16^{\mathrm{bc}}$ & $4.54 \pm 0.21$ & $16.08 \pm 2.50^{\mathrm{a}}$ & $2.14 \pm 0.76$ & $8.9 \pm 2.3^{\mathrm{c}}$ \\
\hline Composite & $3.55 \pm 0.34^{\mathrm{b}}$ & $2.93 \pm 0.21$ & $1.21 \pm 0.10^{\mathrm{b}}$ & $4.55 \pm 0.16$ & $15.28 \pm 1.78^{\mathrm{b}}$ & $2.14 \pm 0.71$ & \multirow{2}{*}{ Tota $=32.5 \pm 5.8$} \\
\hline Proportional & $3.54 \pm 0.35^{\mathrm{b}}$ & $2.93 \pm 0.21$ & $1.21 \pm 0.11^{\mathrm{b}}$ & $4.55 \pm 0.17$ & $15.16 \pm 1.84^{\mathrm{b}}$ & $2.20 \pm 0.72$ & \\
\hline \multicolumn{8}{|c|}{ 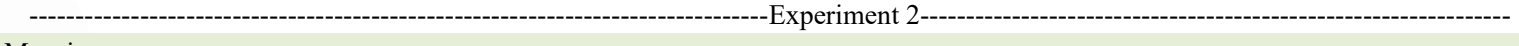 } \\
\hline $\begin{array}{l}\text { Morning } \\
(06: 00)\end{array}$ & $3.23 \pm 0.77^{\mathrm{b}}$ & $3.07 \pm 0.38^{\mathrm{b}}$ & $1.05 \pm 0.23^{\mathrm{b}}$ & $4.43 \pm 0.23$ & $12.23 \pm 2.73^{\mathrm{a}}$ & $2.29 \pm 0.75$ & $15.5 \pm 4.7^{\mathrm{a}}$ \\
\hline $\begin{array}{l}\text { Afternoon } \\
(18: 00)\end{array}$ & $3.57 \pm 0.73^{\mathrm{a}}$ & $3.13 \pm 0.37^{\mathrm{a}}$ & $1.14 \pm 0.21^{\mathrm{a}}$ & $4.47 \pm 0.28$ & $10.57 \pm 2.76^{\mathrm{b}}$ & $2.46 \pm 0.73$ & $13.2 \pm 3.7^{\mathrm{b}}$ \\
\hline Composite & $3.40 \pm 0.68^{\mathrm{ab}}$ & $3.10 \pm 0.37^{\mathrm{ab}}$ & $1.10 \pm 0.19^{\mathrm{ab}}$ & $4.45 \pm 0.24$ & $11.40 \pm 2.60^{\mathrm{ab}}$ & $2.30 \pm 0.71$ & \multirow{2}{*}{ Total $=28.7 \pm 5.3$} \\
\hline Proportional & $3.36 \pm 0.70^{\mathrm{ab}}$ & $3.09 \pm 0.37^{\mathrm{ab}}$ & $1.10 \pm 0.19^{\mathrm{ab}}$ & $4.44 \pm 0.25$ & $11.52 \pm 2.63^{\mathrm{ab}}$ & $2.49 \pm 0.76$ & \\
\hline
\end{tabular}

Mean values in the columns for each experiment with different letters indicate significant difference $(\mathrm{P}<0.05)$. SCC: somatic cell score $\left(\log _{10}\right.$ somatic cells count $\left./ \mathrm{mL}\right)$. 
Protein level was not different among milking sessions in cows milked thrice daily. Nonetheless, in cows milked twice daily, the afternoon milking showed higher protein levels than the morning one. Independently of the number of daily milking, protein levels were not different between composite and proportional samples. Lactose concentration was the same across milking sessions and between proportional and composite samples on both experiments. The milk urea content varied across milking sessions. On cows milked thrice daily, the lowest urea concentration was found in the morning milking and the afternoon milking revealed similar urea concentrations to the evening one. On cows milked twice daily, contrarily, the morning milking session had the highest urea levels. The urea concentrations were similar in proportional and composite samples, independently of the number of daily milking. On cows milked thrice or twice daily the SCC were similar across milking sessions; consequently, proportional and composite samples presented the same values.

\section{DISCUSSION}

Regular milk analysis is essential for maintaining milk quality improvement in a dairy farm. The analyses in a system management consisting of twice or thrice daily milking imply in higher costs, so that the use of proportional or composite samples in order to analyse only one daily sample per cow would be more convenient in dairy control programs by reducing the number of samples needed for analysis. Accordingly, it is essential to know if the milkingto-milking variations may be assimilated in a single composite or proportional sample.

The higher milk yield in the morning milking session agrees with results obtained by other authors (GILBERT et al., 1973; WEISS et al., 2002) who attributed the increase in morning yield to longer milking intervals. Fat is the milk component that varied most, influenced mainly by nutritional and/or metabolic factors and by milking intervals (O'BRIEN et al., 2002). Our study reported lower fat content in the morning samples which may be as describe to a milk dilution effect, once a larger milk volume is present at this time of the day (WEISS et al., 2002). GILBERT et al. (1973) reported higher fat and protein percentages in the evening milking. Proportional or composite sampling showed fat values that were statistically intermediate comparing morning and afternoon/ evening samples. Based on this criterion, milk samples from cows milked thrice daily (Experiment 1) collected only in the afternoon can be conducive to the false- positive diagnosis of ketosis, while in the proportional or composite sampling this misinterpretation does not occur in any of the farms.

Milk protein is the second most variable component, being influenced by the diet and by imbalances in rumen metabolism (GONZALEZ et al., 2000). In agree with results observed on cows milked twice daily, GILBERT et al. (1973) reported that protein levels were higher in the afternoon milking of Holstein cows. It may then be inferred that the dilution effect on the percentage components of milk is noticed mainly in the morning milking sessions. No difference was noted in the protein percentage across the milking sessions as well as in the proportional/ composite samples on cows milked thrice daily. On cows milked twice daily; although, a difference was noted in the protein percentage in the two milking, the proportional/composite samples show statistically intermediate protein percentages comparing morning/ afternoon sessions.

Lactose is the milk component least affected by external factors. The stability in lactose content across the milking sessions reported in this study, and consequently in the composite/proportional samplings, reinforces the idea that this is the more stable molecule of cow's milk (AULDIST et al., 1995; GONZALEZ et al., 2000).

Urea concentration is closely related to the energy and ruminal degradable protein (RDP) available in the diet, as well as to their synchronization. Our study reported conflicting results on both experiments concerning urea concentrations across the milking sessions. Lower urea values were reported in the morning on cows milked thrice daily, while on cows milked twice daily the lower urea values were found in the afternoon. Those finding may be affected by the feeding management of the isolated experiments. In one study using grazing cows supplemented with energy concentrates, NORO et al. (2011) reported higher blood urea concentrations in the morning, while in those not fed with energy concentrates, the highest urea levels were detected in the afternoon. Urea is a blood and milk indicator of current nitrogen balance and it has been established that urea peak in milk occurs 5 hours after feed intake (MOORE; VARGA, 1996) which means that in the morning milking peak urea values should be lower considering the time elapsed after the last feeding of the day. Higher milk urea concentration in the afternoon milking has been reported in dairy cows consuming protein source with different degradability rates (ALVES et al., 2004). In our study, on cows milked thrice daily, proportional/composite samples showed urea values statistically compared to those of 
the afternoon session, while on cows milked twice daily urea values of proportional/composite samples were intermediate between morning and afternoon sessions.

Milk SCC is a recognized indicator of udder health in cows (QUIST et al., 2008). Although, no differences in SCC were detected along the three milking sessions in experiment 1 , a tendency of lower SCC was observed in the morning session that may have been influenced by the dilution effect, due to the higher milk yield at this time of the day (GREEN et al., 2006). The SCC values in proportional/composite samples were statistically similar across milking sessions, independently of the number of daily milking. These results suggested that milk sampling may be either proportional or composite for the evaluation of SCC on farms with twice or thrice daily milking.

\section{CONCLUSION}

The present study showed that lactose levels are not influenced by the time of milking on cows with thrice or twice daily milking sessions. Milk yield is affected by the time of milking with higher values in the morning. Although, protein and fat content, F:P ratio and urea concentration may be influenced by the time of milking in twice daily milking sessions, the composite or proportional samples revealed similar composition to those of the morning and afternoon sessions. In thrice daily milking sessions, the period of sampling affect the values of fat, F:P ratio, urea and SCC, but not of protein. However, proportional and composite samples expressed values that were intermediate among the three periods. As obtaining composite samples is easier than proportional sampling, it is recommended the use of composite sampling as a feasible, inexpensive, and reliable option for determining milk composition on cows milked thrice or twice daily.

\section{DECLARATION OF CONFLICT OF INTERESTS}

The authors declare no conflict of interest. The founding sponsors had no role in the design of the study; in the collection, analyses, or interpretation of data; in the writing of the manuscript, and in the decision to publish the results.

\section{AUTHORS' CONTRIBUTIONS}

The authors contributed equally to the manuscript.

\section{REFERENCES}

ALVES, M. et al. (2004). Feeding dairy cows with soybean byproducts: effects on metabolic profile. Ciência Rural, 34:239-
243. Available: <https://www.ufrgs.br/lacvet/site/wp-content/ uploads/2013/05/alves_vacas_soja.pdf $>$. Accessed: Dec. 08, 2018.

AULDIST, M.J. et al., Changes in the composition of milk from healthy and mastitic dairy cows during the lactation cycle. Austral J. E. Agric. 35:27-36. 1995. Available from: $<$ http://www.publish. csiro.au/an/EA9950427>. Accessed: Dec. 08, 2018. doi: 10.1071/ EA9950427.

BAUMAN, D. E.; GRINARI. J.M. Nutritional regulation of milk fat synthesis. Annu. Rev. Nut. 23:203-227. 2003. Available from: <https://www.ncbi.nlm.nih.gov/ pubmed/12626693>. Accessed: Dec. 08, 2018. doi: 10.1146/ annurev.nutr.23.011702.073408.

CUCUNUBO, L.G. et al., Use of Blood, Urine and Milk Samples in the Diagnosis of Subclinical Ketosis and Negative Energy Balance in Grazing Dairy Cows. Rev. Científica. 23:111-119. 2013. Available from: <https://www.consorciolechero.cl/chile/ documentos/papers/diagnostico-de-cetosis-subclinica-y-balanceenergetico-negativo-en-vacas-lecheras-mediante-el-uso-demuestras-de-sangre-orina-y-leche.pdf > . Accessed: Dec. 08, 2018.

GILBERT, G.R. et al., Diurnal variation in milk yield, fat yield, milk fat percentage and milk protein percentage of HolsteinFriesian cows. J. Dairy Sci. 56:409-410. 1973. Available: <https:// www.journalofdairyscience.org/article/S0022-0302 (73)85187-2/ abstract $>$. Accessed: Dec. 08, 2018. doi: 10.3168/jds.S00220302(73)85187-2.

GONZÁLEZ, F.H.D. et al. Perfil metabólico em ruminantes: seu uso em nutrição e doenças nutricionais, Porto Alegre: Universidade Federal do Rio Grande do Sul, 2000. 106p. il. Available from: < https://www.ufrgs.br/lacvet/restrito/pdf/perfil $\% 20$ nutricional\%20ruminantes.pdf $>$. Accessed: Dec. 08, 2018.

GREEN, L.E. et al. On distinguishing cause and consequence: Do high somatic cell counts lead to lower milk yield or does high milk yield lead to lower somatic cell count? Prev. Vet. Medicine, 76:74 89. 2006. Available from: <https://www.journalofdairyscience. org/article/S0022-0302(73)85187-2/abstract $>$. Accessed: Dec. 08, 2018. doi: 10.3168/jds.S0022-0302(73)85187-2.

MEINERT, T.R. et al. Consideration of percentage of milk shipped for calculation of total lactation yields from various morning and evening plans of milk sampling. J. Dairy Sci. 79:291-300. 1996. Available from: <https://naldc.nal.usda.gov/download/41496/ PDF>. Accessed: Dec. 08, 2018.

MOORE, D.A.; VARGA, G. BUN and MUN: urea nitrogen testing in dairy cattle. Comp. Contin. Educ. Practic. Vet. 18: 712-720.1996. Available from: <http://agris.fao.org/agris-search/ search.do?recordID=US9630604>. Accessed: Dec. 08, 2018.

MURPHY, J.J. et al. Nutritional manipulation of milk protein concentration and its impact on dairy industry. Livest. Product. Sci. 35:117-134. 1993. Available from: $<$ https://www.sciencedirect. com/science/article/pii/030162269390185K>. Accessed: Dec. 08, 2018. doi: 10.1016/0301-6226(93)90185-K.

NIELSEN, N.I. et al. Quarter health, milking interval and sampling time during milking affect the concentration of milk constituents. J. of Dairy Sci. 88:3186-3200. 2005. Available from: <https:// www.journalofdairyscience.org/article/S0022-0302 (05) 730022/abstract>. Accessed: Dec. 08, 2018. doi: 10.3168/jds.S00220302(05)73002-2. 
NORO M., et al. Diurnal Variations in Blood Metabolites Concentration and its Relationship With Feeding Behavior in Lactating Dairy Cows Grazing Permanent Pasture in Spring. Rev. Científica. 21:125-130. 2011. Available from: <https://www. redalyc.org/pdf/959/95918097004.pdf.>. Accessed: Dec. 08, 2018.

NORO, M. WIITTER, F. Relationships between liver urea genesis and gluconeogenesis in ruminants fed with a high nitrogen diet. Vet. México. 43:143-154. 2012. Available from: <http:// veterinariamexico.unam.mx/index.php/vet/article/view/311>. Accessed: Dec. 08, 2018.

O'BRIEN, B., et al. Effect of frequency of milking on yield, composition and processing quality of milk. J. Dairy. Res. 69:367-374. 2002. Available from: <https://www.ncbi.nlm.nih. gov/pubmed/12369407>. Accessed: Dec. 08, 2018.

PALMQUIST, D.L. et al. Milk fat synthesis and modification. Feed and animal factors influencing milk fat composition. J. Dairy
Sci. 76:1753-1771. 1993. Available from: $<$ https://www.cambridge. org/core/journals/journal-of-dairy-research/article/effect-offrequency-of-milking-on-yield-composition-and-processingquality-of-milk/E4CF5AFFE84155F3968AE5ED70BBB0D6>. Accessed: Dec. 08, 2018. doi: 10.1017/S0022029902005605.

QUIST, M.A. et al. Milking-to-milking variability for milk yield, fat and protein percentage, and somatic cell count. J. Dairy Sci. 91: 3412-3423. 2008. Available from: <https://www. sciencedirect.com/science/article/pii/S0022030208710567>. Accessed: Dec. 08, 2018.

WEISS, D., et al. Variable milking intervals and milk composition. Milchwissenschaft. 57:246-249. 2002. Available from: <https://www.researchgate.net/profile/Daniel_Weiss18/ publication/286998874_Variable_milking_intervals_and_ milk_composition/links/581767 6b08aedc7d8968f70b/ Variable-milking-intervals-and-milk-composition.pdf $>$. Accessed: Dec. 08, 2018. 